\title{
15. CHEMISTRY OF HOT WATERS SAMPLED FROM BASALTIC BASEMENT IN HOLE 504B, DEEP SEA DRILLING PROJECT LEG 83, COSTA RICA RIFT ${ }^{1}$
}

\author{
M. J. Mottl and E. R. M. Druffel, Woods Hole Oceanographic Institution \\ S. R. Hart, Massachusetts Institute of Technology \\ J. R. Lawrence, Lamont-Doherty Geological Observatory of Columbia University \\ and \\ E. S. Saltzman, Rosenstiel School of Marine and Atmospheric Science, University of Miami²
}

\begin{abstract}
Seawater that has been altered by reaction with basaltic basement has been sampled from Deep Sea Drilling Project Hole 504B, located on 5.9-m.y.-old crust on the southern flank of the Costa Rica Rift. Fourteen water samples have been collected on Legs 69,70 , and 83 , both before and after renewed drilling on the latter two legs, at temperatures from 69 to $133^{\circ} \mathrm{C}$ and pressures from 390 to 425 bars.

The water sampled prior to renewed drilling on Leg 83 had occupied the hole for nearly 2 yr. since it was last flushed with surface seawater at the end of Leg 70 . Despite some contamination by seawater during sampling, the composition of two of these waters has been determined by using nitrate as a tag for the contaminant. Both the 80 and $115^{\circ} \mathrm{C}$ waters have seawater chlorinity, but have lost considerable $\mathrm{Mg}, \mathrm{Na}, \mathrm{K}$, sulfate, and $\mathrm{O}_{2}$, and have gained $\mathrm{Ca}$, alkalinity, $\mathrm{Si}, \mathrm{NH}_{3}$ and $\mathrm{H}_{2} \mathrm{~S}$. The loss of sulfate is due to anhydrite precipitation, as indicated by the $\delta^{34} \mathrm{~S}$ value of the remaining dissolved sulfate. The ${ }^{87} \mathrm{Sr} /{ }^{86} \mathrm{Sr}$ ratio has been lowered to 0.7086 for the $80^{\circ} \mathrm{C}$ water and 0.7078 for the $115^{\circ} \mathrm{C}$ water, whereas the $\mathrm{Sr}$ concentration is nearly unchanged. The changes in major element composition relative to seawater are also larger for the $115^{\circ} \mathrm{C}$ water, indicating that the basement formation water at this site probably varies in composition with depth. Based on their direction relative to seawater, the compositional changes for the 80 and $115^{\circ} \mathrm{C}$ waters do not complement the changes inferred for the altered rocks from Hole 504B, suggesting that the bulk composition of the altered rocks, like their mineralogy, is largely unrelated to the present thermal and alteration regime in the hole.

The exact nature of the reacted seawaters cannot be determined yet, however. During its 2 yr. residence in the hole, the surface seawater remaining at the end of Leg 70 would have reacted with the wall rocks and exchanged with their interstitial formation waters by diffusion and possibly convection. How far these processes have proceeded is not yet certain, although calculations suggest that diffusion alone could have largely exchanged the surface seawater for interstitial water. The $\delta^{18} \mathrm{O}$ of the samples is indistinguishable from seawater, however, and the $\Delta^{14} \mathrm{C}$ of the $80^{\circ} \mathrm{C}$ sample is similar to that of ocean bottom water. Although the interpretation of these species is ambiguous, that of tritium should not be. Tritium analyses, which are in progress, should clarify the nature of the reacted seawaters obtained from the hole.
\end{abstract}

\section{INTRODUCTION}

Much of the heat associated with seafloor spreading and the cooling of the lithosphere is transported within and removed from the crust by seawater circulating through basaltic basement. Some of this heat exits as spectacular warm or hot springs at the mid-ocean ridge axis, but probably the major fraction is removed away from the axis, along the ridge flanks. The mass of seawater that convects through ridge flanks is large enough to be potentially significant for the geochemical cycles of many elements, including $\mathrm{Mg}, \mathrm{Ca}, \mathrm{Na}, \mathrm{K}$, and $\mathrm{S}$. To evaluate the importance of this process, it is essential to know the direction and extent of chemical exchange that occurs between basalt and the seawater that circulates through it on ridge flanks.

This chemical exchange may be evaluated by studying either the rocks or the solutions. The two types of sam-

\footnotetext{
${ }^{1}$ Anderson, R. N., Honnorez, J., Becker, K., et al., Init. Repts. DSDP, 83: Washington (U.S. Govt. Printing Office).

2 Addresses: (Mottl, Druffel) Woods Hole Oceanographic Institution, Woods Hole, MA 02543; (Hart) Massachusetts Institute of Technology, Cambridge, MA 02139; (Lawrence) Lamont-Doherty Geological Observatory of Columbus University, Palisades, NY 10964; (Saltzman) Rosenstiel School of Marine and Atmospheric Science, University of Miami, Miami FL 33149 .
}

ples provide different information. Because the concentrations of most chemical species are far higher in basalt than in a seawater-derived solution, small amounts of reaction between the two produce much larger changes in the composition of the solution. For the same reason, the solution provides a more instantaneous measure of alteration because results of prior reaction under different conditions are more readily erased. By contrast, the rocks typically retain the effects of alteration over a range of conditions accumulated through time.

Previous attempts to sample basement interstitial waters have been made in DSDP Holes 501, 504B, and 505B on Legs $68-70$ on the southern flank of the Costa Rica Rift (Mottl, Anderson, et al., 1983; Hart and Mottl, 1983), and in Hole 395A near the Mid-Atlantic Ridge on Leg 78B (McDuff, 1984). Most of these samples show small to moderate changes from the composition of seawater and were interpreted as mixtures of a reacted-seawater component with seawater introduced into the hole as a result of drilling. The altered-seawater component had reacted with either sediment, as in Holes 501 and 505B; basalt, as in Hole 504B; or both, as in Hole 395A. Tritium analyses of the Hole 504B waters collected on Leg 69 indicated that they were surface seawater, pumped into the formation only a few days 
earlier during a pressure-pulse test, which had reacted rapidly with the wall rocks at the in situ temperature of $81^{\circ} \mathrm{C}$ (Mottl, Anderson, et al., 1983). In no case has it been possible to estimate the proportion of reacted seawater in a basement borehole water sample, nor to demonstrate that the reacted component is true formation water, that is, interstitial water that was present in the basement rocks prior to drilling.

Renewed drilling in Hole 504B on DSDP Leg 83 provided a third opportunity to sample water from the basement section of this hole. Drilling on Leg 69 had penetrated $274.5 \mathrm{~m}$ of sediment and $214.5 \mathrm{~m}$ of basalt. The sediment section was lined with steel casing on this leg, eliminating the problem of contamination with sediment pore water experienced in Holes 501 and 505B. During Legs 70 and 83, the hole was deepened an additional 347 and $514 \mathrm{~m}$, respectively, for a total basement penetration of $1075.5 \mathrm{~m}$. Borehole water samples were collected on all three legs at temperatures ranging from 69 to $133^{\circ} \mathrm{C}$ (Table 1 and Fig. 1).

The Leg 83 samples display chemical changes that are among the largest seen to date in water collected from basement on a mid-ocean ridge flank. Only Sample PW-5 from Hole 395A shows similarly large compositional changes from seawater (McDuff, 1984). In addition, it has been possible in the case of the Leg 83 samples to determine the composition of the reacted-seawater endmember. The nature of this end-member, however, remains in doubt pending tritium analyses.

\section{SAMPLING METHODS}

A more complete discussion of sampling methods is given by Mottl, Anderson, et al. (1983). As on Leg 70, samples were collected both be- fore and after renewed drilling on Leg 83. The samples may thus be classified as either short-term or long-term, depending on how much time had elapsed since drilling and circulation of drilling fluid (surface seawater) through the hole had ceased. For the short-term samples collected on all three legs, this period ranged from 2 to $74 \mathrm{hr}$. For the Leg 70 long-term samples it was 39 days; for the samples taken at the start of Leg 83, it was 710 days (Table 1).

As on Legs 69 and 70, short-term samples were taken on Leg 83 using both passive and active methods, while long-term samples were taken using the passive method only. In the passive method, water was collected at a known depth from the borehole itself, using either the Barnes-Uyeda tool, the Schlumberger wireline sampler, or the Lynes packer sampler operated in the passive mode. The packer sampler was used to collect large-volume samples and to test for contamination by water from higher in the water column that may have been pushed down the drill pipe by the sampler. The packer sampler can be used for this test because it collects several 8.5 -L aliquots sequentially from one depth in a single sampling episode and segregates them by means of one-way valves. When the packer sampler is operated in the passive mode, the presence of water from higher in the drill pipe is indicated when each successive aliquot differs more from seawater in its composition than the previous one. Every possible precaution was taken on Leg 83 to prevent this kind of contamination, particularly for the long-term samples taken prior to renewed drilling: samples were taken in the sequence listed in Table 1, each at greater depth than had yet been penetrated by either tool or drill pipe, and samplers were allowed to free fall rather than being pumped down the hole. The results from the packer sampler show that, in spite of these precautions, significant amounts of water were introduced to the sampling site from higher in the hole for the Barnes and packer samplers. This probably occurred in part because the outer diameter of the samplers is nearly as large as the inner diameter of the drill pipe. Another possibility is that the samplers leaked before they were opened at the desired sampling depth.

In the active method, the hole was first flushed with surface seawater. Then a Lynes hydraulic packer was used to seal off the bottom of the hole, and water was drawn under negative pressure from the hole and from the interstices of the surrounding rocks. When operated in the active mode, each successive aliquot in the packer sampler should contain a greater proportion of basement interstitial water mixed with surface seawater. This was the case for the Leg 69 sample, but not for

Table 1. Water samples collected from basaltic basement in Hole 504B.

\begin{tabular}{|c|c|c|c|c|c|c|c|c|c|c|}
\hline \multirow[b]{2}{*}{ Leg } & \multirow[b]{2}{*}{ Sample $^{\mathrm{a}}$} & \multirow[b]{2}{*}{$\begin{array}{l}\text { No. of } \\
\text { aliquots }\end{array}$} & \multirow[b]{2}{*}{$\begin{array}{l}\text { Total } \\
\text { Vol. (L) }\end{array}$} & \multicolumn{3}{|c|}{ Depth $(m)^{b}$} & \multirow[b]{2}{*}{$\begin{array}{l}\text { Time since } \\
\text { drilling }^{c}\end{array}$} & \multirow[b]{2}{*}{$\begin{array}{c}\text { Conductive }{ }^{\mathrm{d}} \\
\mathrm{T}\left({ }^{\circ} \mathrm{C}\right)\end{array}$} & \multirow[b]{2}{*}{$\begin{array}{c}\text { Measured }^{\mathrm{e}} \\
\mathrm{T}\left({ }^{\circ} \mathrm{C}\right)\end{array}$} & \multirow[b]{2}{*}{ Method (leg) } \\
\hline & & & & $\begin{array}{l}\text { Below } \\
\text { rig } \\
\text { floor }\end{array}$ & $\begin{array}{l}\text { Below } \\
\text { seafloor }\end{array}$ & $\begin{array}{c}\text { Into } \\
\text { basement }\end{array}$ & & & & \\
\hline 69 & GO-2 & 1 & 2.2 & 3942 & 468.5 & 194 & $70 \mathrm{hr}$. & 80 & $\begin{array}{c}69 \\
(80)\end{array}$ & $\begin{array}{l}\text { GO T-log (69) } \\
\text { Uyeda tool (83) }\end{array}$ \\
\hline 69 & PS & 6-7 & 51 & 3959.5 & 486 & 211.5 & $2 \mathrm{hr}$. & 81.5 & $(81.5)$ & Uyeda tool (83) \\
\hline 70 & IW-173 & 1 & 0.05 & & 355 & 80.5 & 39 days & 68.5 & 8.5 & Uyeda tool (70) \\
\hline 70 & IW-174 & 1 & 0.05 & & 460 & 185.5 & 39 days & 78.5 & $\begin{array}{l}76 \\
(78.5)\end{array}$ & $\begin{array}{l}\text { Uyeda tool (70) } \\
\text { Uyeda tool (83) }\end{array}$ \\
\hline 70 & IW-175 & 1 & 0.05 & & 640 & 365.5 & $24 \mathrm{hr}$. & 98 & $\begin{array}{c}76 \\
(100)\end{array}$ & $\begin{array}{l}\text { Uyeda tool (70) } \\
\text { Uyeda tool (83) }\end{array}$ \\
\hline 70 & IW-194 & 1 & 0.07 & & 715 & 440.5 & $24 \mathrm{hr}$. & 106.5 & (87) & GO T-log (70) \\
\hline 83 & PW-1 & 1 & 0.07 & 3666.5 & 194 & $(-80.5)$ & 710 days & 41 & 5.5 & Uyeda tool (83) \\
\hline & PW-2 & 1 & 0.07 & 3923.5 & 451 & 176.5 & 710 days & 77.5 & 77 & Uyeda tool (83) \\
\hline & PA-1 & $4-6$ & 34 & 3952 & 478.5 & 204 & 710 days & 80.5 & 80.5 & Uyeda tol (83) \\
\hline & PW-3 & 1 & 0.07 & 4123.5 & 650 & 375.5 & 711 days & 100 & 101 & Uyeda tool (83) \\
\hline & PA-2 & 4 & 34 & 4266 & 792.5 & 518 & 711 days & 116 & 115 & $\begin{array}{l}\text { Max. reading } \\
\text { thermometer (83) }\end{array}$ \\
\hline & $\mathrm{SJ}-1$ & 1 & 0.63 & 4452.5 & 979 & 704.5 & $74 \mathrm{hr}$. & 140 & (100) & SJ T- $\log (83)$ \\
\hline & SJ-2 & 1 & 0.62 & 4747 & 1273.5 & 999 & $73 \mathrm{hr}$. & 152.5 & 131 & $\begin{array}{l}\text { Max. reading } \\
\text { thermometer (83) }\end{array}$ \\
\hline & PA-3 & $6-7$ & 51 & 4759 & 1285.5 & 1011 & $2 \mathrm{hr}$. & 153 & (133) & SJ T-log (83) \\
\hline
\end{tabular}

${ }^{\mathrm{a}} \mathrm{GO}=$ Gearhart-Owen tool. PS and PA-3 = Lynes packer sampler with packer set; PA-1 and PA-2, without packer set. IW and PW = Barnes-Uyeda pore water sampler. SJ $=$ Schlumberger tool.

${ }^{b}$ The seafloor is $3473.5 \mathrm{~m}$ below the rig floor. The top of basement is $274.5 \mathrm{~m}$ below the seafloor. Depths below rig floor are for meters of pipe; discrepancies from these values in this table result from tools protruding below the end of the pipe.

c Time elapsed from last circulation of drilling fluid through the hole to sampling.

d Conductive temperature is estimated from the temperature logs taken in basement on Legs 70 and 83 and represents the in situ temperature prior to disturbance by drilling (Becker et al., 1983a, b, this volume).

$\mathrm{e}$ Except for values in parentheses, the measured temperatures are the actual in situ temperatures of the samples as collected. 


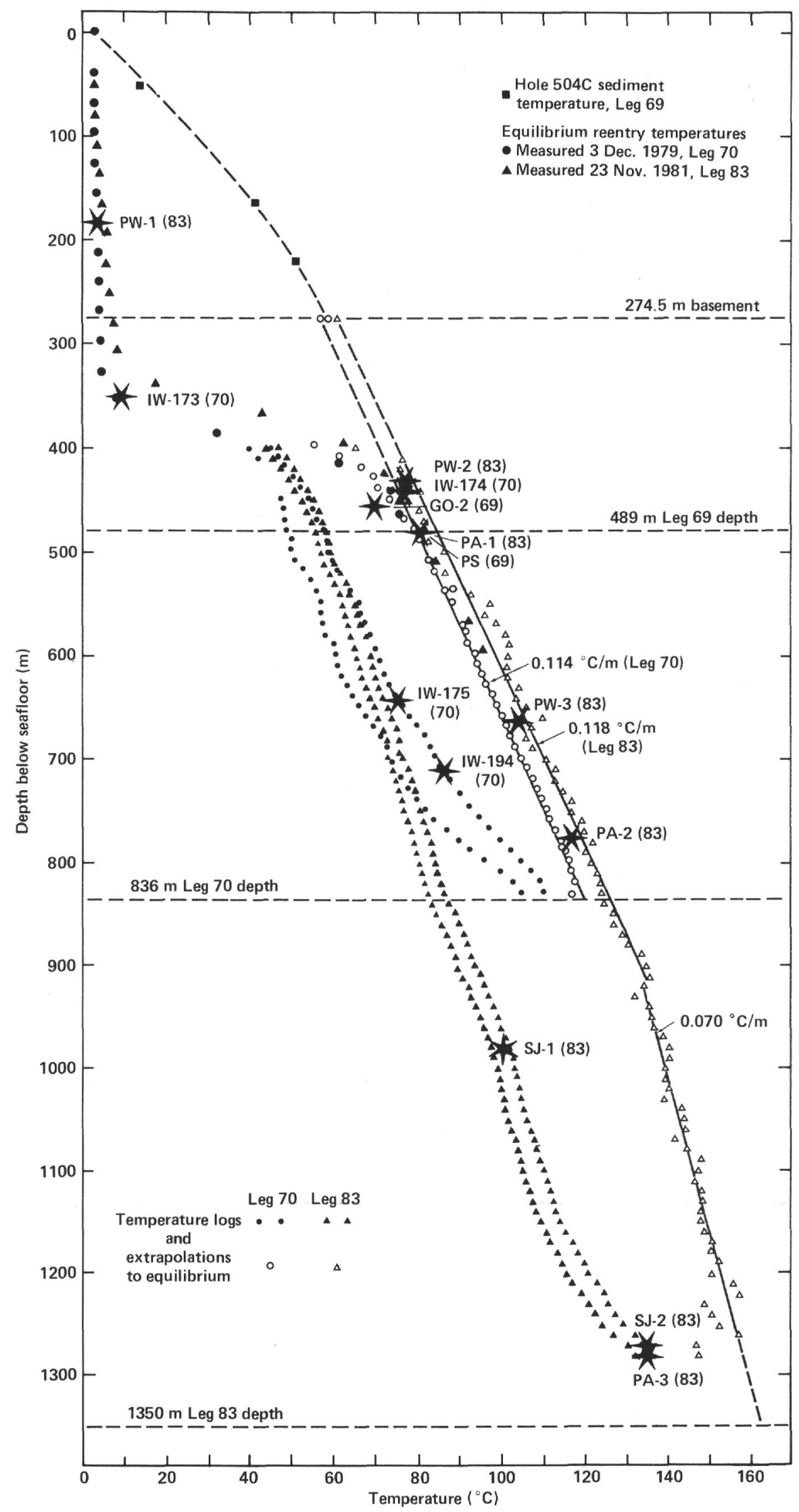

Figure 1. Temperature measurements and water samples taken in Hole 504B on Legs 69, 70, and 83, after Becker et al. (1983b). Equilibrium temperatures indicate downhole flow of bottom water into the upper $\sim 100 \mathrm{~m}$ of basement, at a decaying rate, as confirmed by the upper two water samples. 
the Leg 83 sample, because the packer element did not effectively seal the bottom of the hole while the sample was being drawn.

The temperatures of various samples were measured in situ during collection in most cases (Table 1). The measured temperatures of the short-term samples collected using the passive method differ from the conductive temperatures, which prevailed prior to disturbance by drilling, because some time is required for the hole to thermally reequilibrate.

\section{ANALYTICAL PROCEDURES AND RESULTS}

Unfiltered aliquots from the large samples were taken without contacting the atmosphere and sealed into separate 1-gal. glass jugs for shore-based analyses for tritium and carbon-14 $\left({ }^{14} \mathrm{C}\right)$. For ${ }^{14} \mathrm{C}$ analyses, inorganic carbon was stripped within hours by adding sulfuric acid to the aliquots and recycling a negligible volume of air $(75 \mathrm{ml})$ through them, trapping the $\mathrm{CO}_{2}$ in a solution of $\mathrm{NH}_{4} \mathrm{OH}$ and $\mathrm{SrCl}_{2}$ following the method of Linick (1975). The resulting $\mathrm{SrCO}_{3}$ was returned to the laboratory of E. M. Druffel at Woods Hole and dissolved in $\mathrm{HCl}$; the evolved $\mathrm{CO}_{2}$ was then counted for 6 days in a 200-ml copper gas proportional beta counter at $21^{\circ} \mathrm{C}$ and a pressure of $90 \mathrm{~cm} \mathrm{Hg}$.

Unfiltered aliquots were also used for (1) shipboard analyses for $\mathrm{O}_{2}$ and $\mathrm{H}_{2} \mathrm{~S}$, by standard and modified (Fonselius, 1976) Winkler titration, respectively; (2) shipboard analyses for ammonia and nitrite by colorimetry; and (3) shore-based analyses for $\mathrm{H}_{2} \mathrm{~S}$ precipitated as ZnS immediately on collection, nitrate plus nitrite by auto-analyzer, and $\delta^{34} \mathrm{~S}$ of dissolved sulfate, the latter analyzed by E. S. Saltzmann in the University of Miami laboratory. Except for $\sigma^{34} \mathrm{~S}$, all of the aforementioned analyses were performed on aliquots that had not been exposed yet to the atmosphere and were stored in glass-stoppered oxygen-titration bottles. At this stage most of the solutions were slightly cloudy and had a greenish tinge of the same hue as, and probably due to minor contamination from, the "green grease" (Aqua-Lube, Allube Div., Far Best Corp., Los Angeles, CA) used to lubricate the samplers. After these analyses had been performed and the solutions exposed to the atmosphere, they turned orange as large amounts of rustcolored iron oxyhydroxides precipitated from them. The shore-based analyses for $\mathrm{H}_{2} \mathrm{~S}$ were performed by filtering the greenish solutions, dissolving the filtrate, and analyzing the resulting solution for $\mathrm{Zn}$ via flame atomic absorption spectrophotometry. As is typically the case for this method (J. Gieskes, personal communication, 1983), the values obtained are higher than those from the shipboard titration. The sum of nitrate and nitrite was likewise analyzed on two separate aliquots, both of which were treated with $\mathrm{H}_{2} \mathrm{SO}_{4}$ and $\mathrm{HgCl}_{2}$ immediately on recovery, and one of which was treated with $\mathrm{Zn}$ acetate as well to remove $\mathrm{H}_{2} \mathrm{~S}$. Results from the two aliquots were indistinguishable.

The rest of the analyses were performed on solutions filtered through $0.45-\mu \mathrm{m}$ cellulose membrane filters. These included shipboard analyses for $\mathrm{pH}$, alkalinity, chlorinity, salinity (refractive index), $\mathrm{Ca}$, and $\mathrm{Mg}$ by standard titration techniques (Gieskes, 1974). Shorebased analyses included $\mathrm{K}$ by flame atomic absorption spectrophotometry; $\mathrm{Si}$ by colorimetry; sulfate by ion chromatography; and $\mathrm{Sr}$, $\mathrm{Ba}$, and $\mathrm{B}$ by DC-plasma optical emission spectrometry. Na was calculated from charge balance. $\mathrm{K}, \mathrm{Rb}, \mathrm{Cs}, \mathrm{Sr}, \mathrm{Ba}$, and ${ }^{87} \mathrm{Sr} /{ }^{86} \mathrm{Sr}$ were determined on two samples by S. R. Hart at M.I.T. using isotope dilution mass spectrometry. Details of this procedure are given by Hart and Mottl (1983). Oxygen isotopic analyses were performed on the same two samples by J. R. Lawrence at Lamont-Doherty Geological Observatory.

The analytical results and uncertainties are presented in Table 2. The problem of contamination has been discussed at length by Mottl, Anderson, et al. (1983) and Hart and Mottl (1983). They concluded that $\mathrm{Ca}, \mathrm{Mg}, \mathrm{K}$, and the other major species, plus $\mathrm{Sr}$ and ${ }^{87} \mathrm{Sr} /{ }^{86} \mathrm{Sr}$, are not significantly affected by contamination from barite-bentonite freshwater muds used to flush the hole, whereas $\mathrm{Rb}, \mathrm{Cs}$, and Ba probably are. Their reasoning and conclusions apply to most of the Leg 83 samples as well. The other two sources of contamination, from sediment pore water and from the drilling and sampling apparatus, are not important for the Leg 83 data because (1) the sediment section of Hole 504B was lined with casing on Leg 69 and (2) the elements known to be affected by contamination from the apparatus (Fe, Mn, Li) were not measured.

\section{NATURE OF THE SAMPLES}

The depths of the water samples collected from basement in Hole 504B on Legs 69, 70 and 83 are shown in
Figure 1 along with the measured and conductive temperature profiles. As discussed by Anderson et al. (1982); Becker, Von Herzen, Langseth, et al. (1982); and Becker et al. (1983a, b, this volume), the measured temperature profiles indicate that bottom seawater is flowing down hole and into the basalts within the upper $100 \mathrm{~m}$ of basement, creating a reduction in temperature over this interval that did not exist prior to drilling of Hole 504B. Analyses of the two water samples collected from this interval, prior to renewed drilling on Leg 70 (Sample IW-173 in table 2 of Mottl, Anderson, et al., 1983) and on Leg 83 (Sample PW-1 in table 2), suggest that they are indeed bottom seawater although their silica content is slightly lower than would be expected for bottom water in this area.

With the exception of these two samples, all of the basement water samples from Hole 504B show compositional differences from seawater. The Leg 83 samples, like those from Legs 69 and 70, are mixtures of (1) surface seawater used as drilling fluid and/or (2) bottom seawater that flowed down the hole or was pushed down during the sampling procedure with (3) seawater that has been chemically altered by reaction with the basement basalts. This third, reacted seawater component may be (1) true formation water, which was transported into the hole from the interstices of the surrounding rocks by convective and/or diffusive exchange with the seawater left in the hole after drilling had stopped; (2) seawater left in the hole after drilling that has reacted only briefly with the wall rocks during the time after drilling had stopped and before sampling; or (3) a mixture of the two. The first problem in interpreting the samples is to determine the proportion of reacted seawater in the mixtures and hence its end-member composition. The second problem is to determine the nature of the reacted seawater component, that is, whether it is true formation water or not.

\section{SHORT-TERM SAMPLES}

The short-term samples are those collected near the end of Legs 69, 70, and 83 shortly after the pumping of drilling fluid through the hole had stopped. They include five samples taken using the passive sampling method and two using the active method.

\section{Passive Samples}

All five of the passively collected samples show substantial compositional changes from seawater in spite of having been collected only $24-74 \mathrm{hr}$. after seawater had been pumped through the hole. Because some seawater may have been pushed down the hole during sampling, it is not possible to determine the full extent of this compositional change. Moreover, some of it may be caused by rapid reaction between seawater and barite-bentonite drilling mud, which may not have been completely flushed from the hole prior to sampling. Although the samples contained no mud on recovery, the three passive short-term samples from Legs 69 and 70 contained anomalously high concentrations of $\mathrm{Cs}, \mathrm{Rb}$, and $\mathrm{Ba}$ (Hart and Mottl, 1983) with a $\Delta \mathrm{Rb} / \Delta \mathrm{Cs}$ wt. ratio, relative to seawater concentrations, of 7-24, typical of the $\mathrm{Rb} / \mathrm{Cs}$ ratio in clays. If $\mathrm{Ca}$ were leached from these clays pro- 
portionately to $\mathrm{Cs}$ and $\mathrm{Rb}$, then $40-90 \%$ of the observed $\mathrm{Ca}$ increase in these three samples would be due to reaction with drilling mud. Although similar data are not available for the two passive short-term samples from Leg 83 (Samples SJ-1 and SJ-2, Table 2), water samples collected on a return to Hole 504B on Leg 92 contained drilling mud, indicating that the hole had not been adequately flushed with seawater at the completion of Leg 83 drilling (J. Gieskes, personal communication, 1983).

\section{Active Samples}

Whatever the cause of the compositional changes, the five passive short-term samples generally fall on the same mixing lines between surface seawater and a reacted seawater end-member as do the aliquots from the Leg 69 active short-term sample, as shown by Hart and Mottl (1983). The Leg 69 active sample, taken with the hole sealed by the hydraulic packer, does not exhibit high $\mathrm{Cs}$ and $\mathrm{Rb}$ concentrations. Its compositional changes therefore cannot be attributed to reaction with drilling mud, but must be due to reaction with basalt.

While Mottl, Anderson, et al. (1983) used the oxygen isotope and tritium data to infer that this reaction took place with a small amount of rock over only a few days at $81^{\circ} \mathrm{C}$, McDuff (1984) has argued that it reflects the presence of true formation water, the product of very longterm reaction between seawater-derived interstitial fluid and the basalt of the ocean crust. McDuff calculated, from the absence of an oxygen isotope shift in the sample and its increased chlorinity relative to surface seawater, that the small amount of altered rock would have gained in excess of $39 \mathrm{wt} . \% \mathrm{H}_{2} \mathrm{O}$ if the compositional changes observed in the solution had resulted from shortterm reaction. He considered this to be unreasonably high. However, the most likely products of short-term alteration are palagonite, which can contain more that 30 wt. $\% \mathrm{H}_{2} \mathrm{O}$ (Furnes, 1975), and poorly crystalline smectite. Both palagonite and mature smectite from Hole 504B typically contain 10-20 wt. $\% \mathrm{H}_{2} \mathrm{O}$ (Noack et al., 1983; Honnorez et al., 1983). Basalt glass altered experimentally by seawater at $200^{\circ} \mathrm{C}$ initially took up $30 \mathrm{wt} . \%$ $\mathrm{H}_{2} \mathrm{O}$, based on the observed chlorinity increase; this value dropped with time as the smectite alteration product became better crystallized (Seyfried and Mottl, 1982). Thus, while a minimum of $39 \mathrm{wt} . \%$ water is a high value, it is probably not outside the possible range for the early products of basalt-seawater reaction.

Moreover, although the Leg 69 active sample generally falls on the same mixing lines as the short-term passive samples, it differs greatly from the Leg 83 longterm samples from the same temperature range, as will be shown. This strongly suggests that the Leg 69 active sample does not contain a component of true formation water, but reflects instead only short-term reaction as inferred by Mottl, Anderson, et al. (1983).

As noted earlier, the attempt to sample by the active method on Leg 83 failed because the packer element did not effectively seal the bottom of the hole. Several aliquots of the sample (PA-3 in Table 2) nonetheless vary systematically from one to another, but in the opposite direction from that expected had the hole remained sealed while the sample was drawn: the last aliquots to enter more closely resemble surface seawater, while the earlier aliquots show higher nitrate and lower chlorinity, $\mathrm{Mg}$, $\mathrm{Sr}, \mathrm{K}$, and $\mathrm{pH}$. This trend indicates that (1) the packer seal became less effective with time during sampling and (2) a source of altered seawater was present at the bottom of the hole. The lower chlorinity of this altered seawater strongly suggests that it contains a small fraction of freshwater drilling mud that had not been adequately flushed from the bottom of the hole, probably because the lower $3 \mathrm{~m}$ were filled with basalt rubble from the drilling operation. The nitrate may have come from this drilling mud since no other source for it is apparent. The altered seawater apparently came from the interstices of the rubble, where it had resided for $231 \mathrm{hr}$. between the end of drilling and the sampling episode. It is unique among the present samples in showing $\mathrm{Mg}$ depletion unaccompanied by significant $\mathrm{Ca}$ enrichment. The $\mathrm{Mg}$ depletion is balanced instead by $\mathrm{Na}$ enrichment. This pattern was observed by McDuff (1984) in the deep sample from Hole 395A. He attributed it to basalt alteration accompanied by calcite precipitation. This explanation is consistent with the alkalinity decrease observed in the present sample from Hole 504B.

It is noteworthy that the water from the bottom of Hole 504B reached $133^{\circ} \mathrm{C}$ during its 10 -day residence there, yet shows no sulfate depletion (when corrected to the chlorinity of surface seawater), and thus has not precipitated anhydrite. This is true as well for the Leg 83 short-term passive Samples SJ-1 and SJ-2, which reached 100 and $131^{\circ} \mathrm{C}$, respectively, at about 450 bars pressure, and show $10-40 \%$ enrichments in $\mathrm{Ca}$. These results are consistent with the experiments of Bischoff and Seyfried (1978), in which anhydrite did not precipitate from seawater heated to temperatures of $150^{\circ} \mathrm{C}$ or lower at 500 bars.

\section{LONG-TERM SAMPLES}

The long-term samples from Hole 504B include one taken before the start of renewed drilling on Leg 70 and four taken at the start of Leg 83, in addition to the two samples of bottom seawater flowing down the hole that were discussed earlier. All were taken with the passive method.

Results from the segmented packer sampler indicate that all of the Leg 83 long-term samples contain a large fraction of unreacted seawater that apparently was pushed down the drill pipe by the samplers themselves. For the packer sampler, the four separate aliquots define mixing lines between seawater and a reacted end-member (Figs. 2-6 later). For the Barnes sampler, the two samples both show much smaller compositional changes from seawater than the packer samples taken over the same depth and temperature range of $77-115^{\circ} \mathrm{C}$.

\section{Composition of the Reacted-Seawater End-Member}

The mixing lines defined by the packer aliquots can be used to determine the composition and proportion of the reacted-seawater end-member in the mixture, provided that a suitable "tag" species is available for one of the end-members. An ideal tag would have different 
Table 2. Composition of water samples from basement in Hole 504B collected on Leg 83.

\begin{tabular}{|c|c|c|c|c|c|c|c|c|c|c|c|c|c|c|}
\hline Sample & $\begin{array}{l}\mathrm{pH} \text { at } \\
25^{\circ} \mathrm{C}\end{array}$ & $\begin{array}{l}\text { Salinity } \\
(\% 0)\end{array}$ & $\begin{array}{l}\text { Chlorinity }^{\mathrm{a}} \\
\text { (m) }\end{array}$ & $\begin{array}{l}\text { Alkalinity } \\
(\mathrm{meq} / \mathrm{kg})\end{array}$ & $\begin{array}{l}\mathrm{SO}_{4} \\
(\mathrm{~m})\end{array}$ & $\begin{array}{l}\mathrm{Na} \\
(\mathrm{m})\end{array}$ & $\underset{(\mathrm{m})}{\mathrm{K}}$ & $\begin{array}{l}\mathrm{Ca} \\
(\mathrm{m})\end{array}$ & $\begin{array}{l}\mathrm{Mg} \\
(\mathrm{m})\end{array}$ & $\begin{array}{l}\mathrm{Sr} \\
(\mu)\end{array}$ & $\begin{array}{l}\mathrm{Ba} \\
(\mu)\end{array}$ & $\begin{array}{l}\mathrm{Rb} \\
(\mu)\end{array}$ & $\begin{array}{c}\mathrm{Cs} \\
(\mathrm{nmol} / \mathrm{kg})\end{array}$ & $\begin{array}{c}\text { B } \\
(\mu)\end{array}$ \\
\hline $\begin{array}{c}\text { Surface seawater } \\
(.11 / 23 / 81)\end{array}$ & 7.71 & 34.1 & 524.9 & 2.14 & 27.0 & 450.1 & 9.82 & 9.74 & 50.74 & 85.5 & 0.07 & & & 372 \\
\hline PW-1, prime & 7.60 & 35.2 & 543.3 & 2.45 & 28.2 & 466.3 & 10.12 & 10.25 & 52.49 & 100.0 & 0.15 & & & 384 \\
\hline PW-2, prime & 6.97 & 35.2 & 543.0 & 2.59 & 28.1 & 462.6 & 9.75 & 17.10 & 47.51 & & & & & \\
\hline PW-2, overflow ${ }^{f}$ & 6.67 & 16.5 & 247.1 & & 28.0 & 459.4 & 9.57 & 17.96 & 45.60 & 80.1 & 1.4 & & & 485 \\
\hline PW-3, prime & 6.86 & 35.2 & 541.0 & 2.97 & 27.8 & 466.3 & 9.90 & 12.78 & & & & & & \\
\hline PA-1A (top) & 6.74 & 35.2 & 532.8 & 2.34 & 27.5 & 455.4 & 9.82 & 13.17 & 49.23 & 89.0 & 0.77 & & & 549 \\
\hline PA-1B & 6.76 & 35.2 & 534.8 & 2.47 & 27.0 & 455.3 & 9.47 & 14.77 & 48.40 & 89.6 & 0.93 & & & 494 \\
\hline PA-1C & 6.68 & 35.2 & 538.2 & 2.34 & 26.0 & 452.7 & 9.11 & 20.64 & 44.65 & 91.1 & 0.78 & & & 536 \\
\hline PA-1D (bottom) & 6.81 & 35.2 & 545.0 & 2.56 & 25.8 & 458.3 & 9.09 & 22.40 & 43.37 & 91.7 & 1.59 & & & 548 \\
\hline PA-1D via IDMS' & & & & & & & 8.85 & & & 89.6 & 2.35 & 1.40 & 8.74 & \\
\hline PA-2A (top) & 6.49 & 34.9 & 533.1 & 1.62 & 19.0 & 431.2 & 7.50 & 36.63 & 30.30 & 83.0 & 1.30 & & & 794 \\
\hline PA-2B & 6.30 & 34.9 & 544.1 & 1.80 & 17.7 & 441.4 & 7.33 & 38.55 & 27.65 & 80.6 & 0.67 & & & 606 \\
\hline PA-2C & 6.56 & 34.9 & 545.5 & 2.52 & 17.7 & 438.2 & 7.27 & 40.14 & 28.73 & 86.5 & 1.91 & & & 588 \\
\hline PA-2D (bottom) & 6.51 & 34.9 & 546.9 & 2.48 & 17.6 & 439.3 & 7.18 & 40.14 & 28.82 & 86.3 & 1.31 & & & 570 \\
\hline $\begin{array}{l}\text { Surface seawater } \\
(12 / 23 / 81)\end{array}$ & 8.00 & 34.1 & 521.3 & 2.19 & & & & 9.87 & 49.94 & & & & & \\
\hline $\mathrm{SJ}-1$ & 7.24 & 34.1 & 521.8 & 1.84 & 26.9 & 442.5 & 9.44 & 14.05 & 48.65 & 82.6 & 1.02 & & & 402 \\
\hline $\mathrm{SJ}-2$ & 6.73 & 33.8 & 519.6 & 1.83 & 27.2 & 447.0 & 9.54 & 11.24 & 48.28 & 87.8 & 0.58 & & & 427 \\
\hline PA-3A (top) & 6.13 & 33.8 & 513.4 & 1.63 & 26.4 & 442.5 & 9.51 & 9.86 & 47.96 & 77.6 & 0.68 & & & 354 \\
\hline PA-3B & 6.33 & 33.8 & 515.6 & 1.55 & 26.4 & 444.5 & 9.61 & 9.82 & 48.05 & 80.3 & 0.60 & & & 450 \\
\hline PA-3C & 6.36 & 33.6 & 513.6 & 1.68 & 26.5 & 442.2 & 9.56 & 9.77 & 48.41 & 81.3 & 1.06 & & & 455 \\
\hline PA-3D & 6.46 & 33.6 & 518.4 & 1.70 & 26.3 & 446.6 & 9.54 & 9.73 & 48.51 & 82.3 & 0.62 & & & 442 \\
\hline PA-3E & 6.49 & 33.8 & 515.3 & 1.71 & 26.4 & 442.7 & 9.68 & 9.70 & 48.96 & 80.9 & 0.65 & & & 354 \\
\hline PA-3F & 6.58 & 33.8 & 521.5 & 1.41 & 26.7 & 449.1 & 9.64 & 9.83 & 48.90 & 85.0 & 0.69 & & & 355 \\
\hline PA-3G (bottom) & 6.56 & 33.8 & 519.6 & 1.72 & 26.9 & 448.6 & 9.72 & 9.79 & 48.51 & 85.2 & 0.73 & & & 401 \\
\hline Uncertainty $(\%)$ & & 0.5 & 1 & 2 & 1 & 1 & 2 & 2 & 2 & 2 & & 1 & 3 & 6 \\
\hline
\end{tabular}

Note: Units are $\mathrm{mmol}(\mathrm{m})$ or $\mu \mathrm{mol}(\mu)$ per $\mathrm{kg}$ of solution unless noted otherwise.

a As mmol/kg chloride, equals chlorinity $(\%) \div 35.453 \times 1000$.

b By modified Winkler titration (Fonselius, 1976) performed in the shipboard laboratory immediately on collection.

${ }^{\mathrm{C}}$ By precipitation as $\mathrm{ZnS}$ followed by shore-based filtration, dissolution, and analysis for Zn via flame atomic absorption spectrophotometry. Values for the PA-3 aliquots are maxima, as they were exposed to the atmosphere and precipitated Fe-oxyhydroxides prior to analysis.

$\mathrm{d}$ The uncertainties represent one standard deviation about the mean for replicate countings of a single aliquot of each sample.

e Of the dissolved sulfate sulfur only. These are preliminary data, uncorrected for the value of $\delta^{18} \mathrm{O}$ in the $\mathrm{SO}_{2}$ gas. Correction is expected to lower these values

f $\mathrm{pH}$, salinity, and chlorinity are as measured on the aliquot from the overflow chamber that is diluted with distilled water during sampling. Values for all other chemical species have been normalized to the chlorinity of the prime (undiluted) aliquot.

$\mathrm{g}$ As analyzed by S. R. Hart using isotope-dilution mass spectrometry. Accuracies are $\leq 0.5 \%$ for $\mathrm{K}$ and $\mathrm{Sr}$, $\leq 1 \%$ for Rb, and $3 \%$ for Cs and Ba. Analytical uncertainties for ${ }^{87} \mathrm{Sr} / 86 \mathrm{Sr}$ given in the table are $\pm 2 \sigma$.

$\mathrm{h}$ As measured on the combined $2 \mathrm{C}$ and $2 \mathrm{D}$ aliquots. These two aliquots were not separated by one-way valves, which probably accounts for their relative homogeneity.

but known concentrations in the two end-members and would behave conservatively when they mixed.

Although less than ideal, the most useful species for the present samples is nitrate, which has a high concentration in ocean bottom water, but would be absent in the reacted end-member, considering that the samples were found to contain appreciable $\mathrm{H}_{2} \mathrm{~S}$ (Table 2). The disadvantage of nitrate is that it tends to react with $\mathrm{H}_{2} \mathrm{~S}$ or $\mathrm{Fe}^{2+}$ on mixing to form nitrite and/or ammonia plus oxidized sulfur species ranging from sulfur to sulfate. Nitrate reduction is not a rapid reaction, however (Stumm and Morgan, 1970). Figure 2 shows that for packer Sample PA-1 collected at $80^{\circ} \mathrm{C}$, the four successive aliquots define a mixing line on a plot of $\mathrm{Ca}$ versus nitrate plus nitrite that passes near to but below the composition of bottom seawater. A similar result is obtained when nitrate plus nitrite is plotted against any other major species in seawater. The sum of nitrate plus nitrite has been plotted because the minor amounts of nitrite present (Table 2) almost certainly resulted from nitrate reduction during the few hours between collection of the samples and their recovery and treatment. Note that oxygen was not detectable in Sample PA-1, even though the ali- quots analyzed contain up to $44 \%$ of the unreacted seawater end-member. Presumably the oxygen has been reduced by reaction with $\mathrm{H}_{2} \mathrm{~S}$ and possible $\mathrm{Fe}^{2+}$ from the reacted end-member. That the mixing line for Sample PA-1 in Figure 2 passes slightly below bottom seawater indicates that the seawater pushed down the drill pipe by the sampler contains a component from higher in the water column. This is a feature of the mixing lines for most of the other species as well (Figs. 3-5). Note in Figure 2 that the short-term passive samples have very low nitrate, as would be expected for reacted or unreacted surface seawater.

The mixing line for PA- 1 in Figure 2 extrapolates to a $\mathrm{Ca}$ concentration of $28.4 \mathrm{mmol} / \mathrm{kg}$ where nitrate goes to zero. This is considered to be the $\mathrm{Ca}$ concentration in the nitrate-free, reacted-seawater end-member that was present at this depth in the hole prior to sampling. The richest aliquot contains $67 \%$ of this end-member.

The four aliquots from packer Sample PA-2, collected at $115^{\circ} \mathrm{C}$, are not obviously linear when plotted against $\mathrm{Ca}$ (Fig. 2). A line forced through them, moreover, would pass well above the composition of bottom seawater. It is probable that nitrate reduction has occurred more 
Table 2. (Continued).

\begin{tabular}{|c|c|c|c|c|c|c|c|c|c|c|}
\hline $\begin{array}{c}\mathrm{Si} \\
(\mu)\end{array}$ & $\begin{array}{c}\mathrm{NH}_{3} \\
(\mu)\end{array}$ & $\begin{array}{c}\mathrm{NO}_{2} \\
(\mu)\end{array}$ & $\underset{(\mu)}{\mathrm{NO}_{3}}+\mathrm{NO}_{2}$ & $\begin{array}{l}\mathrm{O}_{2} \\
(\mu)\end{array}$ & $\underset{(\mu)}{\Sigma \mathrm{H}_{2} \mathrm{~S}^{\mathrm{b}}}$ & $\underset{(\mu)}{\mathrm{SH}_{2} \mathrm{~S}^{\mathrm{c}}}$ & $\begin{array}{c}\Delta^{14} C^{\mathrm{d}} \\
(\%)\end{array}$ & $\begin{array}{l}\delta^{34} \mathrm{~S}^{\mathrm{e}} \\
(\%)\end{array}$ & $\begin{array}{c}\delta^{18} \mathrm{O} \\
(\%)\end{array}$ & ${ }^{87} \mathrm{Sr} /{ }^{86} \mathrm{Sr}$ \\
\hline 5.38 & & & 0.70 & 202 & & & $+130 \pm 23$ & 20.2 & & \\
\hline 120 & $\begin{array}{r}<10 \\
30\end{array}$ & & & & & & & & & \\
\hline 715 & 100 & & & & & & & & & \\
\hline 472 & 100 & & & & & & & & & \\
\hline 400 & 35 & 2 & 27.5 & & 14 & 27 & $-222 \pm 14$ & 19.8 & & \\
\hline 435 & 15 & 2 & 20.4 & & 13 & 30 & $-271 \pm 25$ & 19.9 & & \\
\hline 564 & 30 & 2 & 13.9 & $<7$ & 11 & 28 & $-251 \pm 14$ & 19.9 & & \\
\hline 622 & 10 & 2 & 10.4 & $<4$ & 7 & 23 & $-192+15$ & 19.9 & +0.02 & $0.70877 \pm 2$ \\
\hline 1396 & 95 & $\leq 0.2$ & 10.6 & & 23 & 23 & $+41 \pm 14$ & 19.3 & & \\
\hline 1280 & 76 & $\leq 0.2$ & 9.97 & & 22 & 12 & $-56 \pm 14$ & & & \\
\hline 1800 & 83 & 0.5 & 2.52 & & 17 & & $-242 \pm 14^{\mathrm{h}}$ & 19.2 & & \\
\hline \multirow[t]{2}{*}{1881} & 62 & 0.4 & 2.59 & & 22 & 36 & $-242 \pm 14^{h}$ & 19.3 & +0.2 & \\
\hline & $<10$ & 0 & 0.22 & 202 & 0 & & & & & \\
\hline 550 & 12 & $<0.4$ & 0.30 & & & & & & & \\
\hline 1115 & & $<0.2$ & 0.47 & & & & & & & \\
\hline 298 & 75 & $<0.4$ & 7.61 & & & $<66$ & & & & \\
\hline 314 & 70 & $<0.4$ & 8.14 & & & $<47$ & & & & \\
\hline 288 & 60 & $<0.4$ & 3.85 & & 0.8 & $<63$ & & & & \\
\hline 267 & 70 & $<0.4$ & 1.55 & & 2 & $<86$ & & & & \\
\hline 278 & 50 & $<0.4$ & 1.70 & 0.3 & 0 & $<90$ & & & & \\
\hline 283 & 65 & 0.4 & 1.33 & & 12 & $<24$ & & & & \\
\hline 319 & 65 & 3 & & & & & & & & \\
\hline 3 & 10 & & 4 & & & & & & & \\
\hline
\end{tabular}

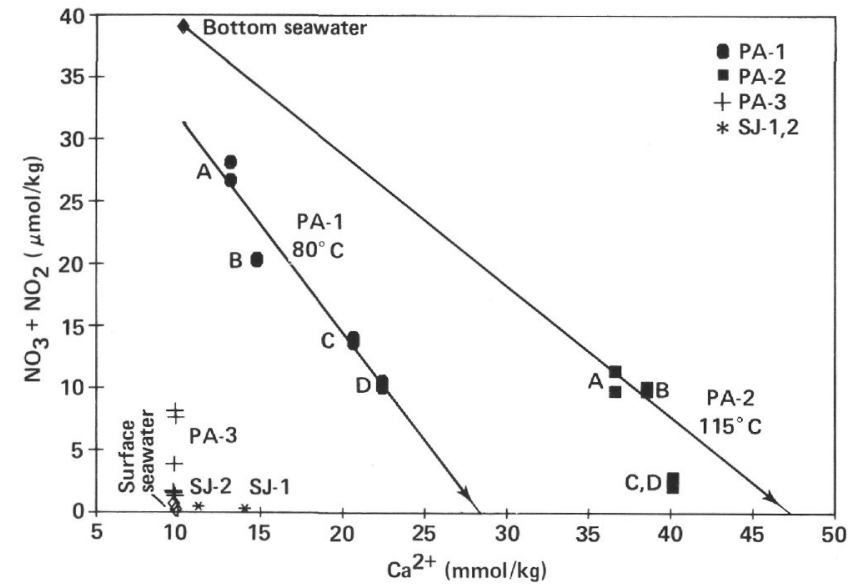

Figure 2. Ca versus nitrate plus nitrite in the Leg 83 basement water samples from Hole 504B. The end-member compositions extrapolated from the measured values for the PA-1 and PA-2 aliquots are designated by arrows.

rapidly in this sample on mixing, considering its higher temperature and lower proportion of unreacted seawater. This would be especially true for the two richest aliquots. A conservative estimate of the reacted end-member composition can be obtained by assuming that nitrate reduction has been significant only in these two aliquots. A line passing through the other two aliquots and bottom seawater then yields a $\mathrm{Ca}$ concentration of $47.4 \mathrm{mmol} / \mathrm{kg}$ at zero nitrate and an $80 \%$ fraction of the reacted-seawater end-member in the two richest aliquots.
Using the $\mathrm{Ca}$ concentrations determined for the nitrate-free, reacted-seawater end-member at 80 and $115^{\circ} \mathrm{C}$, the mixing lines in Figures 3-8 can be extrapolated to determine the composition of the waters that occupied the drillhole at the corresponding depths prior to sampling. These compositions are given in Table 3, along with that of the interstitial water from the overlying basal sediments.

A confirmation that the extrapolated compositions are reasonable is provided by the chlorinity data in Figure 3 . The extrapolated chlorinities are barely distinguishable from those of the basal sediment pore water in Hole 504B and from bottom seawater, given the analytical uncertainty. As with nitrate, the chlorinity data suggest that a sizable component of unreacted seawater from higher in the water column is present in the PA-1 aliquots, but not in those from the deeper Sample PA-2.

\section{Nature of the Reacted-Seawater End-Member}

Whereas the compositional changes in the short-term samples can all be explained by reaction alone, the processes of diffusive and convective exchange with the interstitial waters in the wall rocks become potentially important for the long-term samples.

At the end of Leg 70, Hole 504B was thoroughly flushed and filled with surface seawater. It was then left undisturbed for nearly 2 yr. prior to collection of the Leg 83 long-term samples. The chief question regarding the nature of the reacted-seawater end-member in these samples is whether it includes any remnant of the surface seawater left in the hole 2 yr. earlier. A second important question is whether a component of the bottom 
Table 3. Composition of three deep waters from Hole 504B, in $\mathrm{mmol} / \mathrm{kg}$.

\begin{tabular}{|c|c|c|c|c|c|c|c|c|c|c|c|c|c|}
\hline \multirow[b]{2}{*}{ Type } & \multirow[b]{2}{*}{ Sample } & \multicolumn{2}{|c|}{ Depth (m) } & \multirow[b]{2}{*}{$\mathrm{T}\left({ }^{\circ} \mathrm{C}\right)$} & \multirow[b]{2}{*}{ Chlorinity } & \multirow[b]{2}{*}{$\mathrm{SO}_{4}$} & \multirow[b]{2}{*}{$\mathrm{Na}$} & \multirow[b]{2}{*}{$\mathrm{Na} / \mathrm{Cl}$} & \multirow[b]{2}{*}{$\mathrm{K}$} & \multirow[b]{2}{*}{$\mathrm{Ca}$} & \multirow[b]{2}{*}{$\mathrm{Mg}$} & \multirow[b]{2}{*}{$\mathrm{Si}$} & \multirow[b]{2}{*}{${ }^{87} \mathrm{Sr} /{ }^{86} \mathrm{Sr}$} \\
\hline & & $\begin{array}{l}\text { Below } \\
\text { seafloor }\end{array}$ & $\begin{array}{c}\text { Into } \\
\text { basement }\end{array}$ & & & & & & & & & & \\
\hline $\begin{array}{l}\text { Basal sediment pore water } \\
\text { Basement borehole water }\end{array}$ & $36^{\mathrm{a}}$ & 261.8 & -12.7 & 57 & 545.5 & 21.4 & 461.3 & 0.8456 & $\sim 6$ & 32.6 & 27.7 & 0.75 & \\
\hline end members ${ }^{b}$ & PA-1 & 478.5 & +204 & 80 & 549.5 & 24.6 & 456.3 & 0.8304 & 8.6 & 28.5 & 39.6 & 0.76 & 0.7086 \\
\hline & PA-2 & 792.5 & +518 & 115 & 549.9 & 14.9 & 435.2 & 0.7914 & 6.7 & 47.4 & 21.9 & 2.2 & 0.7078 \\
\hline Bottom seawater ${ }^{c}$ & PW-1 & & & & 543.3 & 28.2 & 466.3 & 0.8584 & 10.1 & 10.3 & 52.5 & 0.12 & 0.7091 \\
\hline
\end{tabular}

${ }^{\mathrm{a}}$ From Mottl, Anderson, et al. (1983), converted to $\mathrm{mmol} / \mathrm{kg}$ by dividing by 1.0243 .

$\mathrm{b}$ Determined by extrapolating mixing lines defined by aliquots $\mathrm{A}$ to $\mathrm{D}$ to an assumed value of zero for $\left(\mathrm{NO}_{3}^{-}+\mathrm{NO}_{2}^{-}\right)$in the end-member. Changes in the PA-2 samples relative to seawater may be underestimated, as they are based on a conservative extrapolation. See text for further explanation.

${ }^{\mathrm{c}}$ Sample PW-1 was collected within the cased sediment section in the upper part of the hole. As bottom seawater is inferred from the temperature profiles in Figure 1 to be flowing downward through this part of the hole, PW-1 is here taken to be representative of bottom seawater.

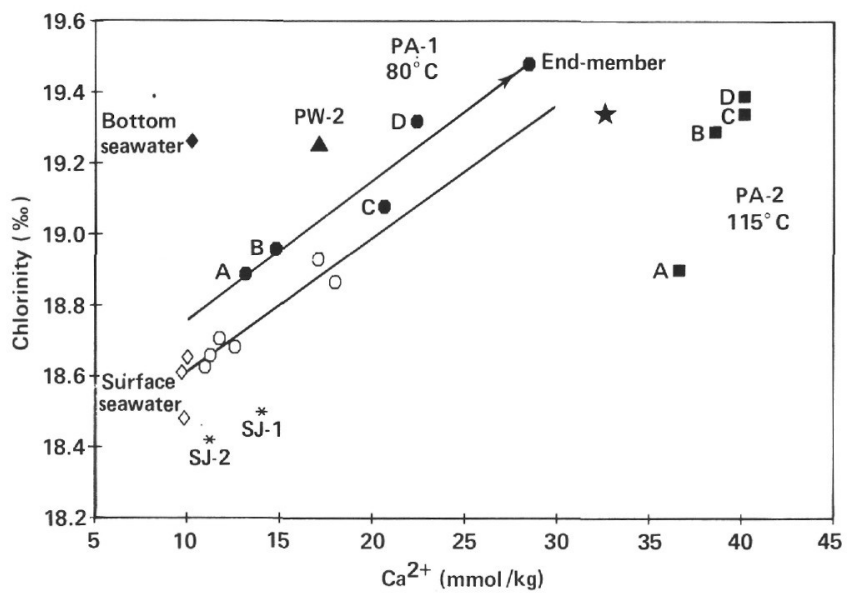

Figure 3. Ca versus chlorinity in the Leg 83 basement water samples from Hole 504B compared with the Leg 69 active sample (open circles) and the basal sediment pore water (star). Other symbols as in Figure 2.

seawater known to be flowing down the hole at shallow levels during this period has made its way into samples taken from deeper in the hole. Such a bottom-seawater component would differ from that introduced during sampling and evaluated in the previous section in that it would have had sufficient time to react significantly with the wall rocks in the hole, thereby changing in composition. The seawater introduced during sampling generally has not had sufficient time to react with the rocks, or even to precipitate anhydrite, as evidence by the mixing lines passing through seawater composition (Figs. 4, 5). It apparently has gained $\mathrm{Si}$, however (Fig. 6).

Nitrate is, of course, not a useful tag for bottom seawater that has had time to react with the rocks. Nor is tritium useful, as it is absent in the water column in this area below $600 \mathrm{~m}$. The ${ }^{14} \mathrm{C}$ data are ambiguous, as will be shown. In the absence of a suitable tag, the best evidence that bottom seawater flowing down the hole has not penetrated to the depth of the samples is the difficulty in transporting it to sufficient depth. The temperature profiles from Legs 70 and 83 (Fig. 1) indicate that the water flowing downward disappears into the upper $\sim 100 \mathrm{~m}$ of basement (Becker et al., 1983b, this volume), more than $100 \mathrm{~m}$ and $400 \mathrm{~m}$ above the depth of Samples PA-1 and PA-2, respectively. Over the interval above Sample PA-1, the temperature rebounds sharply to the overall conductive gradient in the hole. Even with the large temperature gradient over this interval, however, convection within the hole itself is unlikely because of its geometry, which would require cells having an extreme aspect ratio. Deeper in the hole, the conductive temperature gradient and the difference in the end-member compositions of Samples PA-1 and PA-2 suggest that vertical convection in the hole is negligible to nonexistent, as rapid convection in this direction would tend to erase the vertical gradients. Vertical transport by diffusion can be ruled out because of the time required: even with a diffusion coefficient as high as $10^{-4} \mathrm{~cm}^{2} / \mathrm{s}$, the mean diffusion path $(D t)^{1 / 2}$ over 711 days is only $78 \mathrm{~cm}$.

For any surface seawater remaining in the hole after 2 yr., tritium is an ideal tag: it is present in high concentrations in the surface waters ( $~ 2.5$ T.U.; Mottl, Anderson et al., 1983); it is absent in both bottom seawater and formation water; and it is virtually nonreactive with the rocks. Tritium analyses are in progress in the laboratory of W. J. Jenkins at Woods Hole, but are not yet available. In any case, it is worthwhile to evaluate the effect of diffusion and convection on the surface seawater left in the hole, using tritium as a representative nonreactive species.

\section{Role of Diffusive and Convective Exchange}

The effect of diffusion has been considered by McDuff (1984) for waters sampled from Hole 395A 5 yr. after it was drilled. Given that the vertical gradients are small compared with the horizontal gradients between the seawater left in the hole and the interstitial water in the surrounding rocks, the problem reduces to the twodimensional case of an infinitely long cylinder of one medium surrounded by an infinite volume of another. The diffusion coefficients are uniform within each medium, but change abruptly at the boundary between them. Because a solution to this problem is not readily available, McDuff (1984) reduced it to the one-dimensional case by modifying the equations of Crank (1975, p. 58). He approximated the differing diffusion coefficients $(D)$ in the two media by assuming that the water in the hole was well mixed during the process. The onedimensional case underestimates the rate of change of water composition in the hole by effectively doubling the unit volume of the cylinder (by making each infini- 

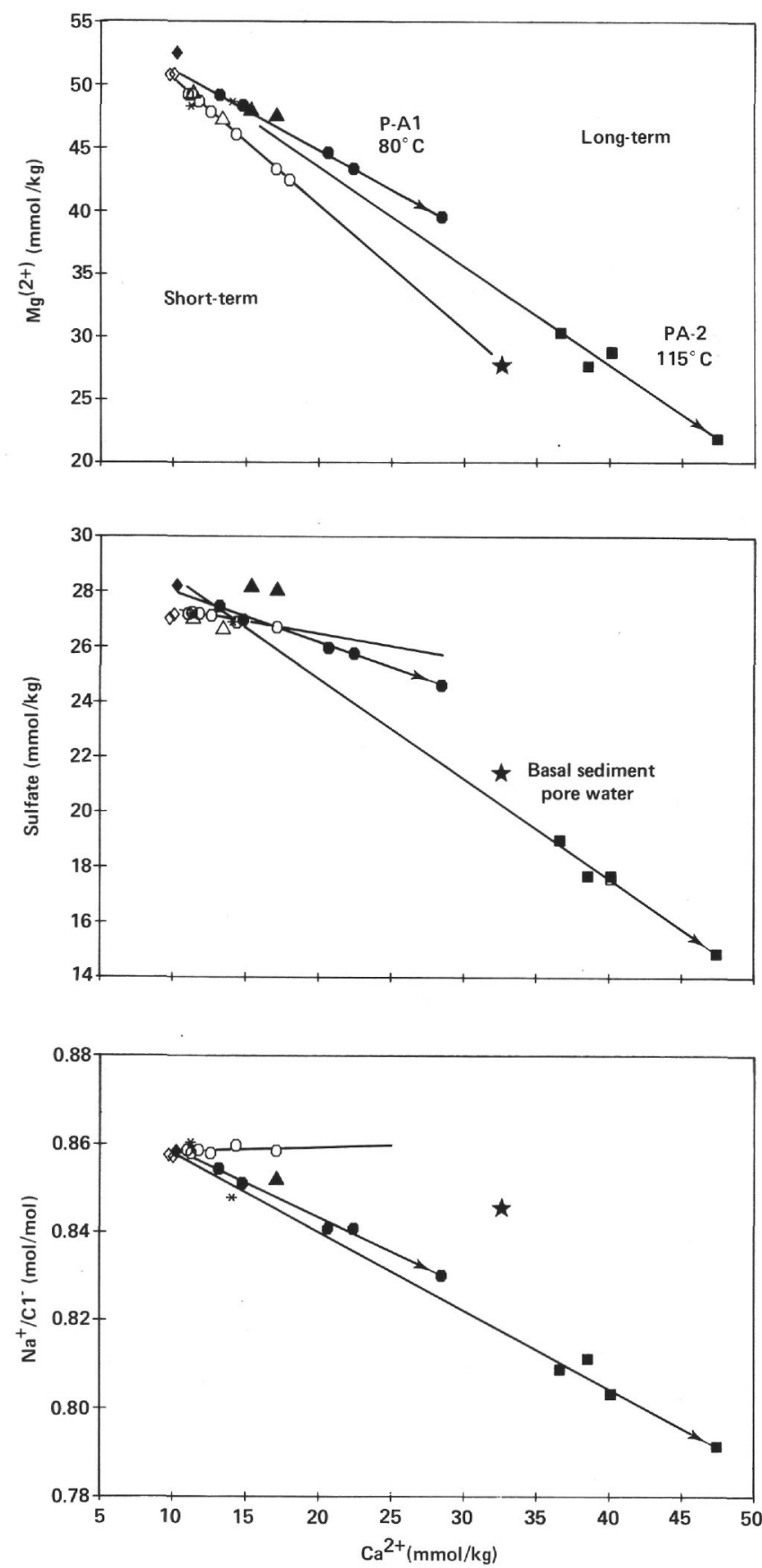

Figure 4. Ca versus $\mathrm{Mg}$, sulfate and $\mathrm{Na} / \mathrm{Cl}$ in the basement water samples from Hole 504B compared with the basal sediment pore water (star). Solid symbols are bottom seawater (diamond) and longterm samples from Leg 70 (one triangle) and Leg 83 (all others). Open symbols are surface seawater (diamonds) and short-term samples from Legs 69 (circles), 70 (triangles), and 83 (asterisks). Least-squares regression lines are defined by the Leg 69 and 83 samples only, excluding the seawater and reacted-seawater endmembers. The latter are designated by arrows.

tesimal radial increment effectively rectangular rather than wedge-shaped), whereas the assumption of wellmixed water in the hole overestimates it by overestimating the gradient and resulting flux at the boundary. The overall effect of these assumptions can be seen by comparing McDuff's (1984) results with those for two other simplified cases: (1) the same one-dimensional case, but
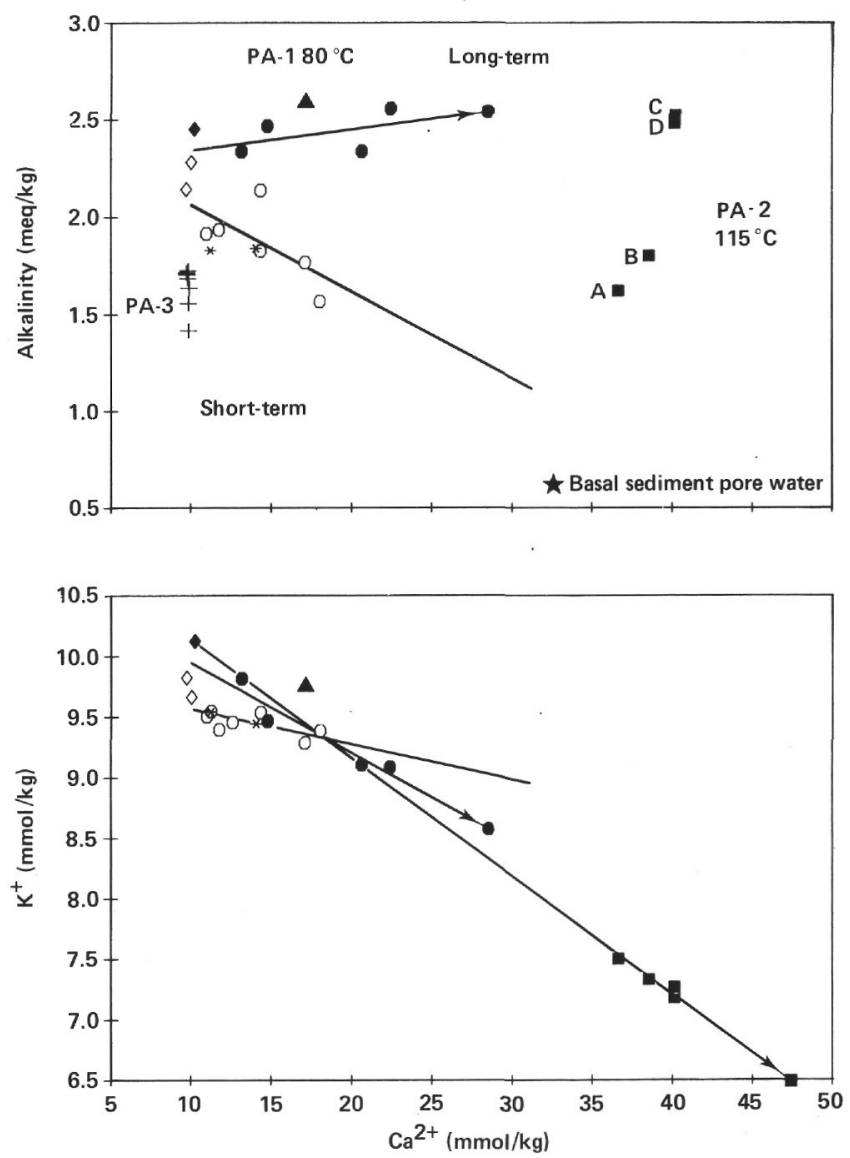

Figure 5. Ca versus alkalinity and $\mathrm{K}$ in the Leg 83 basement water samples from Hole 504B compared with the Leg 69 samples (open circles) and the basal sediment pore water (star). Symbols are the same as those in Figures 2 and 3.

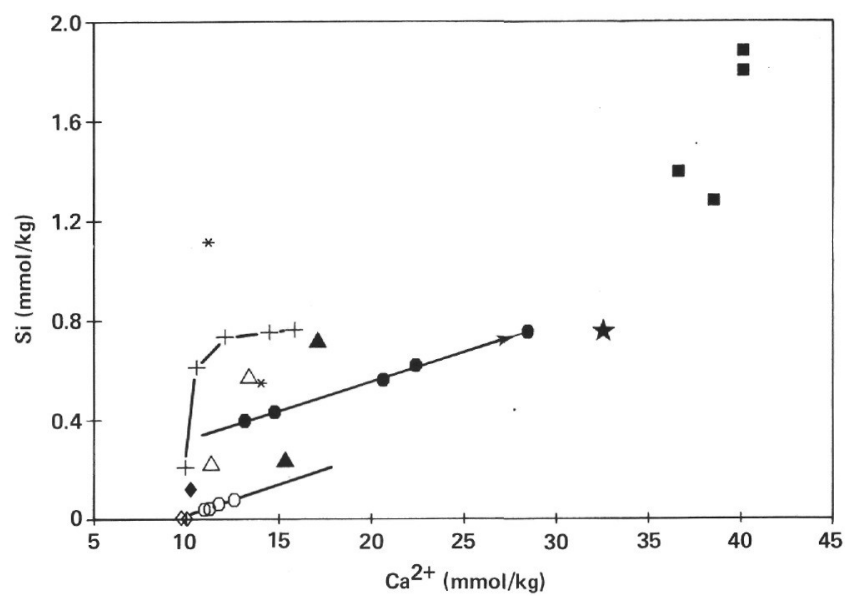

Figure 6. Ca versus $\mathrm{Si}$ in basement water samples from Hole 504B compared with the basal sediment pore water (star) and the timedependent experimental results of Seyfried and Bischoff (1979) reacting basalt glass with seawater at $70^{\circ} \mathrm{C}$ and one atmosphere (plusses). Other symbols are the same as those in Figure 4.

with the same $D$ in both media (Crank, 1975, p. 15), and (2) the two-dimensional case of a cylinder, again with the same $D$ in both media (Crank, 1975, p. 30). The results for all three cases, along with an estimate for 
the actual case based on the differences obtained from the three simplified cases, are given for tritium in Table 4 for values of $D$ in the basement interstitial water ranging from $10^{-7}$ to $10^{-5} \mathrm{~cm}^{2} / \mathrm{s}$. For the in situ temperatures of $76-115^{\circ} \mathrm{C}$, the likely range for $D$ is $10^{-6}$ to $10^{-5}$ $\mathrm{cm}^{2} / \mathrm{s}$, although the actual values for basalts are not well known.

The results in Table 4 show that the one-dimensional assumption produces a larger error than the assumption of a well-mixed water in the hole. This can be seen from the fact that the two-dimensional case with constant $D$ (Case 3 in Table 4) produced more rapid exchange than either of the one-dimensional cases despite its tendency to underestimate the rate of exchange by assuming that $D$ is similar in both the hole and the interstices of the rock. The greatest uncertainty, however, derives from the large range in the estimate for $D$. When the Leg 83 samples were collected, anywhere from 4 to $40 \%$ of the original surface seawater tritium may still have resided in the hole after $2 \mathrm{yr}$. if diffusion were the only process operating and $D$ is in the range of $10^{-5}$ to $10^{-6}$. The same proportion applies to the chemical anomalies for other species in surface seawater compared with the basement formation water.

The role of convective exchange has also been discussed by McDuff (1984). Given the conductive temperature gradient over depth range sampled in Hole 504B, the only relevant case is that of horizontal flow across the hole unaccompanied by vertical flow either up or down in the hole. McDuff (1984) has noted that convective exchange will dominate diffusive exchange when the velocity of horizontal flow exceeds the ratio $D / r$, where $r$ is the radius of the hole. For $D=10^{-6}$ to $10^{-5} \mathrm{~cm}^{2} / \mathrm{s}$ and $r=14 \mathrm{~cm}$, the horizontal velocity would have to exceed 2 to $20 \mathrm{~cm} / \mathrm{yr}$. in order for convection to dominate.

If horizontal flow has exceeded $20 \mathrm{~cm} / \mathrm{yr}$, then the surface seawater would have been effectively flushed from the hole and the sample end-members (Table 3) would

Table 4. Calculated values for surface-seawater tritium remaining in Hole 504B at the time of long-term sampling on Legs 70 and 83, for three simplified cases plus an estimate for the actual case.

\begin{tabular}{|c|c|c|c|c|c|c|}
\hline \multirow[b]{2}{*}{ Case } & \multicolumn{3}{|c|}{$\begin{array}{l}\text { After } 39 \text { days } \\
\text { (Leg 70) }\end{array}$} & \multicolumn{2}{|c|}{$\begin{array}{l}\text { After } 711 \text { days } \\
\text { (Leg 83) }\end{array}$} & \multirow[b]{2}{*}{$10^{-}$} \\
\hline & $10^{-7}$ & $10^{-6}$ & $10^{-5}$ & $10^{-7}$ & $10^{-6}$ & \\
\hline 1. 1-d, constant $D$ & 2.46 & 2.31 & 1.94 & 2.28 & 1.73 & 0.76 \\
\hline 2. 1-d, well mixed & 2.42 & 2.20 & 1.68 & 2.11 & 1.48 & 0.7 \\
\hline 3. Cylinder, constant $D$ & 2.4 & 2.15 & 1.57 & 2.1 & 1.22 & 0.19 \\
\hline $\begin{array}{l}\text { 4. Cylinder, variable } D \\
\text { (estimate for actual } \\
\text { case) }\end{array}$ & 2.4 & 2.1 & 1.3 & 2.0 & 1.0 & 0.1 \\
\hline
\end{tabular}

Note: Values are the mean concentrations in the hole, in tritium units, assuming that the surface seawater contained 2.53 TU and that mass transfer has occurred by horizontal diffusion alone. $1-\mathrm{d}=$ one-dimensional.

a Diffusion coefficient in $\mathrm{cm}^{2} / \mathrm{s}$ for the interstitial water in the rocks surrounding the hole alone ( 2 and 4 ) or for the interstitial water plus the water in the hole itself ( 1 and 3 ).

$\mathrm{b}$ The actual case is taken to be that of a cylinder of unit height at a given depth and temperature with a value for $D$ appropriate for diffusion through an open volume of solution, surrounded by an infinitely extensive medium of porous rock at the same temperature with a value for $D$ appropriate for diffusion through the interstitial solution in the rock. represent true basement formation water. A volume of interstitial water equal to the volume of the hole exists within $0.5 \mathrm{~m}$ of the axis of the hole, and 10 hole volumes within $1.5 \mathrm{~m}$, given the porosity of $8 \%$ (Becker, Von Herzen, Francis, et al., 1982; Cann and Von Herzen, 1983). The hole likewise would contain nearly pure formation water if the diffusion coefficients were $10^{-5}$ $\mathrm{cm}^{2} / \mathrm{s}$ or greater. This fact severely limits the ability of tritium analyses to detect the presence of horizontal convection if tritium should prove to be absent or nearly so in the samples. However, if tritium proves to be present, then an upper limit may be placed on the in situ diffusion coefficient for the basement interstitial waters, as well as on the velocity of horizontal convection.

In summary, the calculated results in Table 4 suggest that the end-member compositions in Table 3 may closely resemble true basement formation water as a result of diffusive exchange alone. If convection and, as is likely, reaction have also occurred, then the end-members for the Leg 83 long-term samples would resemble the basement formation waters even more closely. How closely should be verifiable by tritium analyses.

\section{Significance of the Reacted End-Member Compositions}

\section{Oxygen Isotopes}

A possible problem with the foregoing conclusion is raised by the oxygen isotope data in Table 2 . The two aliquots analyzed were indistinguishable from seawater. If a large fraction of formation water is indeed present in the samples, this formation water must have a $\delta^{18} \mathrm{O}$ value near $0 \%$. This would be surprising in light of the depletion of up to $-5 \%$ observed in the sediment pore waters from nearby holes and attributed by Mottl, Lawrence, et al. (1983) to reaction in the basement. Alternatively, the samples may be mainly surface seawater that has reacted for $2 \mathrm{yr}$. with only a negligible mass of rock, as inferred for the Leg 69 samples (Mottl, Anderson, et al., 1983). This seems unlikely for the Leg 83 samples in light of the objections raised by McDuff (1984). It also would imply that the in situ diffusion coeffcients are considerably less than $10^{-6} \mathrm{~cm}^{2} / \mathrm{s}$. Again, the tritium results should clarify this problem.

\section{Carbon-14}

This species was originally measured to estimate the proportion of basement formation water in the samples. To be used in this way, the residence time of formation water in crust would have to be long enough ( $>50,000 \mathrm{yr}$.) for ${ }^{14} \mathrm{C}$ to be essentially absent in the formation water, as is the case with tritium. Carbon-14 differs from tritium, however, in two ways: it is present in bottom seawater, and it could be affected significantly by reaction with fresh or altered basalt.

The ${ }^{14} \mathrm{C}$ data are plotted against $\mathrm{Ca}$ in Figure 7. The aliquots for the deeper Sample PA-2 define a line that passes unrealistically far above even surface seawater. Aliquot $\mathrm{A}$ is known to have been contaminated by air during stripping, as a leak was found in the transfer tub- 


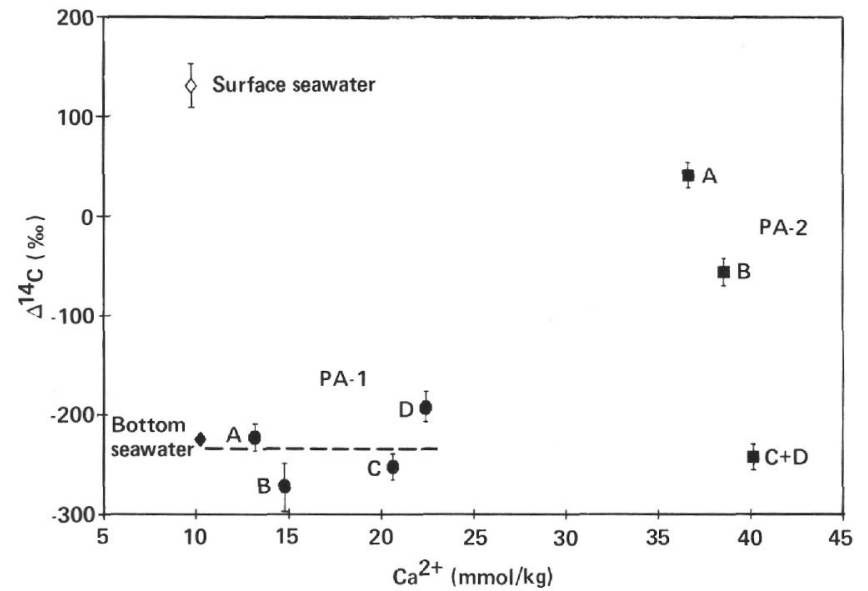

Figure 7. Ca versus $\Delta^{14} \mathrm{C}$ for surface seawater and the aliquots from Samples PA-1 and PA-2 collected on Leg 83. The bottom-seawater value is taken from the GEOSECS profiles (Östlund and Stuiver, 1980). The dashed line is the mean value for the four PA-1 aliquots.

ing. It must be concluded from its high value that Aliquot $\mathrm{B}$ also suffered contamination, rendering the data for Sample PA-2 useless.

The aliquots for Sample PA-1 are not obviously contaminated. The four $\Delta^{14} \mathrm{C}$ values are all within $2 \sigma$ of the average value $(-234 \pm 34,1 \sigma)$, which is similar to that in the lower half of the water column at this locality $(-210$ to $-240 \% 0)$, as measured in the GEOSECS profiles (Östlund and Stuiver, 1980). Barring contamination, this implies that the reacted seawater end-member also has about the same ${ }^{14} \mathrm{C} /{ }^{12} \mathrm{C}$ ratio as near-bottom seawater. The possibility that the end-member is bottom seawater that flowed down the hole and then reacted with the rocks was discussed earlier and considered to be unlikely on physical grounds. If the end-member is surface seawater that has exchanged with the wall rocks via diffusion, reaction, and possibly convection, as inferred earlier, then its $\Delta^{14} \mathrm{C}$ value would have changed from +130 to $-234 \% 0$ over 2 yr.

This change could have resulted from exchange of carbon with the wall rocks or with their interstitial solutions. Secondary carbonates are known to be present at the depth of Sample PA-1, mainly as aragonite in veins. Calcite occurs as vesicle and void fillings only a few meters higher (Honnorez et al., 1983; Noack et al., 1983). PA-1 end-member solution has gained alkalinity relative to surface seawater (Fig. 5), suggesting a calculated value for total $\mathrm{CO}_{2}$ of about $2.9 \mathrm{mmol} / \mathrm{kg}$, compared with $2.2 \mathrm{mmol} / \mathrm{kg}$ in surface seawater. Simple dilution of surface seawater carbon by this amount with nonradioactive carbon from the rocks would lower $\Delta^{14} \mathrm{C}$ from +130 to $-143 \%$. Exchange of carbon during reaction would lower this value even further. Diffusive exchange with the interstitial waters by itself could lower $\Delta^{14} \mathrm{C}$ from +130 to a value in the range of -550 to $-950 \%$, given the calculated values in Table 4 for $D=10^{-6}$ to $10^{-5}$ and assumming that ${ }^{14} \mathrm{C}$ is absent in the interstitial waters.
Thus, either reaction or diffusion by itself could explain the observed $\Delta^{14} \mathrm{C}$ values for Sample PA-1. Since both have definitely occurred, and if bottom seawater has not in fact flowed down to the sampling depth, we must conclude that either (1) the PA-1 aliquots somehow were contaminated with atmospheric ${ }^{14} \mathrm{C}$, (2) the correct value for $D$ is less than $10^{-6} \mathrm{~cm}^{2} / \mathrm{s}$, or (3) the formation waters are not "dead" with respect to radiocarbon. The uniform and relatively low values for the four aliquots argue against contamination. If it has not occurred, and if $D \geq 10^{-6}$, an upper limit can be placed on the residence time of the formation water in the crust. For the PA-1 end-member to have $\Delta^{14} \mathrm{C}$ as high as $-250 \%$, the formation water could be no lower than $-500 \%$, even when the possible effects of reaction and of a higher carbon concentration in the formation water versus seawater are ignored altogether. $A$ value of $-500 \%$ would prevail for the case in which $D=10^{-6}$, and $40 \%$ of the surface seawater remained in the hole after 2 yr. (see Table 4). A value of $-500 \%$ for the formation water would imply a residence time in the crust of less than 3600 yr. Given that the sample was recovered from $478.5 \mathrm{~m}$ below the seafloor, this would imply a minimum vertical flow velocity through $274.5 \mathrm{~m}$ of sediment and $204 \mathrm{~m}$ of basement of $13 \mathrm{~cm} / \mathrm{yr}$.

\section{Major Species in Seawater}

Data for $\mathrm{Ca}$ versus $\mathrm{Mg}$, sulfate, $\mathrm{Na}, \mathrm{K}$, and alkalinity are plotted in Figures 4 and 5 . For every species, the long-term samples from 80 and $115^{\circ} \mathrm{C}$ define mixing lines that differ from each other and from that for the short-term active sample from Leg 69 , taken at $81^{\circ} \mathrm{C}$. The extrapolated end-member compositions also differ from each other and from the basal sediment pore water sample collected at $57^{\circ} \mathrm{C}$ (Table 3).

The major differences between the short-term and longterm samples from about $80^{\circ} \mathrm{C}$ are that (1) the shortterm gain of $\mathrm{Ca}$ from the rock is balanced almost entirely by loss of $\mathrm{Mg}$ from solution, whereas the long-term $\mathrm{Ca}$ gain is balanced by loss of $\mathrm{Na}$ as well as $\mathrm{Mg}$; (2) the long-term sample has lost more $\mathrm{K}$ and sulfate than the short-term sample; and (3) the short-term sample has lost alkalinity whereas the long-term sample has gained it. The first two differences are consistent with time-dependent variation in reaction progress between basalt and seawater (Seyfried and Bischoff, 1979; Mottl and Holland, 1978). The reason for the third difference is unclear. Taken at face value, it implies that the shortterm sample has precipitated carbonate but the longterm sample has dissolved it. It is unlikely to have resulted from the redox reactions that occurred during sampling, when unaltered seawater was mixed with the water in the hole. These reactions consisted mainly of oxidation of $\mathrm{H}_{2} \mathrm{~S}$ and possibly $\mathrm{Fe}^{2+}$ by introduced oxygen, by lesser amounts of nitrate, and possibly by $\mathrm{Fe}^{3+}$ from drill pipe. Most of the likely reactions consume alkalinity. This and the low concentrations of these species relative to the measured alkalinity suggest that these reactions played a minor role in the long-term samples. Their role in the short-term samples is difficult to evalu- 
ate, as the proportion of reacted end-member in these samples is unknown.

The differences between the long-term samples from 80 and $115^{\circ} \mathrm{C}$ indicate that the formation-water composition varies with temperature and depth: gain of $\mathrm{Ca}$ and loss of $\mathrm{Mg}$, sulfate, $\mathrm{Na}$, and $\mathrm{K}$ to the altered rocks all increase with temperature. The composition of the basal sediment pore water from $57^{\circ} \mathrm{C}$ does not fit neatly into this trend, except for $\mathrm{Na}$ : its concentrations of $\mathrm{Ca}$, $\mathrm{Mg}$, and sulfate are intermediate, whereas its losses of $\mathrm{K}$ and alkalinity are larger and reverse the temperature trend set by two basement samples. This suggests that the sediment pore water composition may be determined to a great extent by reactions within the sediments themselves.

The depletion in sulfate shown by both basement water samples apparently results from anhydrite precipitation rather than from reduction to sulfide, as indicated by the sulfur-isotope data in Table 2. Compared with the short-term samples discussed earlier, which had not precipitated anhydrite in spite of their higher temperatures, the long-term samples reached saturation because of their higher content of $\mathrm{Ca}$, leached from the rocks. Anhydrite occurs in Hole 504B at the depth of Sample PA-2, but not a the shallower depth of Sample PA-1 (Anderson et al., 1982; Honnorez et al., 1983; Alt et al., 1983; Alt, Saltzman, and Price, this volume). This is consistent with the suggestion that the crust at this locality is presently heating up.

\section{Silicon}

Data for $\mathrm{Si}$ are plotted against $\mathrm{Ca}$ in Figure 6. As with the major species, its concentration is temperaturedependent. Values for the $80^{\circ} \mathrm{C}$ end-member agree well with those found in the basalt-seawater experiments of Seyfried and Bischoff $(1979)$ at $70^{\circ} \mathrm{C}$ also shown in Figure 6. Concentrations at both 80 and $115^{\circ} \mathrm{C}$ exceed quartz saturation slightly at the prevailing pressures of about 390 and 425 bars, respectively.

\section{Strontium and Its Isotopes}

Strontium concentrations are little changed from that in seawater. Strontium isotope ratios are plotted along with the extrapolated end-member values in Figure 8. They decrease with temperature and are lower in the long-term samples from Leg 83 than in the short-term samples from Legs 69 and 70 . Some of the decrease may be due to reaction with carbonates, especially for the $80^{\circ} \mathrm{C}$ sample where aragonite is present in the altered rocks, as noted earlier. For the $115^{\circ} \mathrm{C}$ sample, calcite occurs only a few meters deeper in the hole, as reported by Honnorez et al. (1983).

\section{Species Involved in Redox Reactions}

These species include $\mathrm{NH}_{3}$ and $\mathrm{H}_{2} \mathrm{~S}$, as well as nitrate, nitrite, oxygen, and ferrous and ferric iron, which have already been discussed. Whereas the short-term samples contain little $\mathrm{NH}_{3}$ (Mottl, Anderson, et al., 1983), the Leg 83 long-term samples have appreciable concentrations that increase with temperature. Hydrogen sulfide likewise was not detected in the Leg 69 samples,

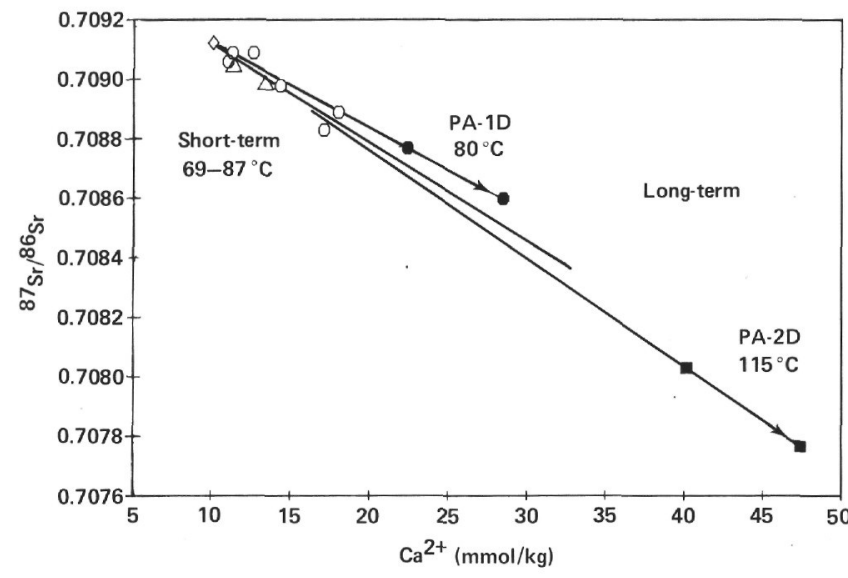

Figure 8. Ca versus ${ }^{87} \mathrm{Sr} /{ }^{86} \mathrm{Sr}$ for two aliquots from the Leg 83 longterm samples (solid symbols) compared with the short-term samples (open symbols) from Leg 69 (circles) and Leg 70 (triangles), and surface seawater (diamond). Compositions of the Leg 83 reacted-seawater end-members were extrapolated from surface seawater through one data point each and are designated by arrows. Analytical uncertainty for ${ }^{87} \mathrm{Sr} /{ }^{86} \mathrm{Sr}$ is equal to the height of the symbols.

even by odor, but in the Leg 83 long-term samples it was measured in low concentrations. The lack of measurable oxygen in the samples, even when large proportions of bottom seawater introduced during sampling were present, suggests that the in situ concentrations of $\mathrm{H}_{2} \mathrm{~S}$ are higher than those measured by as much as a factor of 7 . This factor could be even larger if $\mathrm{H}_{2} \mathrm{~S}$ was oxidized by $\mathrm{Fe}^{3+}$ from the drill pipe and by $\mathrm{NO}_{3}^{-}$as well as $\mathrm{O}_{2}$ during and after sampling.

\section{Relationship to the Altered Rocks}

Examination of the recovered core indicates that alteration in the basement section varies with depth (Anderson et al., 1982; Honnorez et al., 1983; Alt, et al., this volume). Oxic to anoxic low-temperature weathering products characterize the upper $310 \mathrm{~m}$ of basement. From 254 to $297 \mathrm{~m}$ into basement zeolite-filled veins cut the low-temperature assemblage. Alteration is exclusively anoxic below $310 \mathrm{~m}$. From 310 to $614 \mathrm{~m}$ the assemblage is saponite, smectite-chlorite, calcite, pyrite, and minor quartz, talc, and anhydrite, which from oxygenisotopic studies apparently formed at $60-110^{\circ} \mathrm{C}$ (Alt et al., 1983). This compares with a present $T$ range over that depth interval of $95-135^{\circ} \mathrm{C}$. From 614 to $907 \mathrm{~m}$ the assemblage is mainly from the greenschist facies, with a lower $T\left(<235^{\circ} \mathrm{C}\right)$ laumontite-bearing assemblage in veins. From 850 to $1075.5 \mathrm{~m}$ the rocks are less altered, to both zeolite and greenschist facies assemblages. In general, the alteration does not appear to be related to the present thermal regime in the hole.

Bulk chemical changes in the rocks in the upper $310 \mathrm{~m}$ of basement that are due to alteration consist of slightly decreased $\mathrm{MgO}$ and increased $\mathrm{K}_{2} \mathrm{O}, \mathrm{H}_{2} \mathrm{O}^{+}, \delta^{18} \mathrm{O}, \mathrm{Fe}^{3+}$ / $\mathrm{Fe}^{2+}$ ratio, and possibly $\mathrm{CaO}$ (Honnorez et al., 1983). Sample PA-1 is from this zone. The chemical changes for $\mathrm{Mg}$ and $\mathrm{Ca}$ in the Sample PA-1 solution are the opposite of what would be expected for a solution comple- 
mentary to these rocks, although the $\mathrm{K}$ change is complementary. Below $310 \mathrm{~m}$ the trends reverse: the rocks have gained $\mathrm{MgO}$ and possibly ${ }^{18} \mathrm{O}$ and lost $\mathrm{CaO}$ and $\mathrm{K}_{2} \mathrm{O}$. The Sample PA-2 solution from $518 \mathrm{~m}$ into basement thus complements the rocks for $\mathrm{Mg}$ and $\mathrm{Ca}$ but not for $\mathrm{K}$. These results suggest that the bulk composition of the altered rocks, like their mineralogy, is largely unrelated to the present alteration regime in the hole, as reflected in the solution chemistry.

\section{CONCLUSION}

Experience in sampling waters from the basement section of Hole 504B on Legs 69, 70, and 83 indicates that there are two main problems in collecting and interpreting them. The first is avoiding contamination from sediment pore water, drilling mud, water from depths in the drill pipe or hole other than the depth being sampled, and the drilling and sampling apparatus itself. The second is determining the nature of the water once its uncontaminated composition is known. By using a combination of sampling technique and interpretation of chemical data for various "tag" species, it has been possible for the first time with the Leg 83 samples to overcome most of these problems.

Of the two main sampling methods, both are probably capable of obtaining samples from which the composition of true basement water can be inferred. The active method of drawing water from the interstices of the wall rocks with the packer set is by far the more difficult technically. Although, for a variety of operational reasons, it has yet to obtain an unambiguous sample, it certainly is capable of doing so under the proper circumstances. The passive method of sampling water from a given depth in the drill hole itself has limited usefulness except for holes like Holes 395A and 504B, which are reentered months to years after drilling. Such holes provide the simplest and best opportunity for sampling basement formation water, especially if (1) their sediment section has been lined with casing as with Hole 504B and (2) they were thoroughly flushed with seawater when drilling stopped to remove the drilling mud. Although casing is expensive, flushing is not and should be done routinely in every basement hole that is likely to be reentered at a later date.

The success of the Leg 83 sampling resulted largely from casing, flushing, and the long time elapsed since drilling. Even then, the samples would have been uninterpretable had it not been for the use of the large-volume segmented sampler. This sampler not only demonstrated that contamination with water from elsewhere in the hole was a common problem but provided a way to deal with it. Thus, extrapolation to zero nitrate could be used to determine for the first time the composition of the reacted-seawater end-member from a basement hole.

The nature of this basement water can be determined by modeling the chemical and physical processes that could have affected the surface seawater left in hole during the 2 yr. between drilling and sampling and then comparing the modeling results with the data for various "tag" species. The processes include reaction with the wall rocks and diffusive and convective exchange with their interstitial solutions. The most useful "tag" species is tritium, for which analyses are in progress. Although preliminary interpretation suggests that the Leg 83 samples consist largely of true formation water, a definitive result awaits the tritium data.

\section{ACKNOWLEDGMENTS}

We wish to thank especially Drs. Joris Gieskes and Russ McDuff for their helpful comments and suggestions on both the research and the manuscript and Barry Grant of MIT for performing an initial set of sulfate analyses. This work was supported by U. S. National Science Foundation Grant OCE83-00481. This is WHOI Contribution No. 5577.

\section{REFERENCES}

Alt, J. C., Honnorez, J., Hubberten, H.-W., and Saltzman, E., 1983. Occurrence and origin of anhydrite from Deep Sea Drilling Project Leg 70, Hole 504B, Costa Rica Rift. In Cann, J. R., Langseth. M. G., Honnorez, J., Von Herzen, R. P., White, S. M., et al., Init. Repts. DSDP, 69: Washington (U.S. Govt. Printing Office), 547-550.

Anderson, R. N., Honnorez, J., Becker, K., Adamson, A. C., Alt, J. C., Emmermann, R., Kempton, P. D., Kinoshita, H., Laverne, C. Mottl, M. J., and Newmark. R. L., 1982. Deep Sea Drilling Project Hole 504B: The first reference section over $1 \mathrm{~km}$ through Layer 2 of the oceanic crust. Nature, 300:589-594.

Becker, K., Langseth, M. G., and Von Herzen, R. P., 1983 (cited as 1983a). Deep crustal geothermal measurements, Hole 504B, Deep Sea Drilling Project Legs 69 and 70. In Cann, J. R., Langseth, M. G., Honnorez, J., Von Herzen, R. P., White, S. M., et al., Init. Repts. DSDP, 69: Washington (U.S. Govt. Printing Office), 223235.

Becker, K., Langseth, M. G., Von Herzen, R. P., and Anderson, R. N., 1983 (cited as 1983b). Deep crustal geothermal measurements, Hole 504B, Costa Rica Rift. J. Geophys. Res., 88:3447-3457.

Becker, K., Von Herzen, R. P., Francis, T. J. G., Anderson, R. N., Honnorez, J., Adamson, A. C., Alt, J. C., Emmermann, R., Kempton, P. D., Kinoshita, H., Laverne, C., Mottl, M. J., and Newmark, R. L., 1982. In situ electrical resistivity and bulk porosity of the oceanic crust Costa Rica Rift. Nature, 300:594-598.

Becker, K., Von Herzen, R. P., Langseth, M. G., Anderson, R. N., and the Leg 83 Scientific Party, 1982. Geothermal and electrical logging of DSDP Hole 504B, Costa Rica Rift. EOS, 63:434.

Bischoff, J. L., and Seyfried, W. E., Jr., 1978. Hydrothermal chemistry of seawater from $25^{\circ}$ to $350^{\circ} \mathrm{C}$. Am. J. Sci., 278:838-860.

Cann, J. R., and Von Herzen, R. P., 1983. Downhole logging at Deep Sea Drilling Project Sites 501, 504, and 505, near the Costa Rica Rift. In Cann, J. R., Langseth, M. G., Honnorez, J., Von Herzen, R. P., White, S. M., et al., Init. Repts. DSDP, 69: Washington (U.S. Govt. Printing Office), 281-299.

Crank, J., 1975. The Mathematics of Diffusion: (2nd ed.): London (Oxford University Press).

Fonselius, S. H., 1976. Determination of hydrogen sulphide. In Grasshoff, K. (Ed.), Methods of Seawater Analysis, Verlag Chemie, 71-78.

Furnes, H., 1975. Experimental palagonitization of basaltic glasses of varied composition. Contrib. Mineral. Petrol., 50:105-113.

Gieskes, J. M., 1974. Interstitial water studies, Leg 25. In Simpson, E. S. W., Schlich, R., et al., Init. Repts. DSDP, 25: Washington (U.S. Govt. Printing Office), 361-394.

Hart, S. R., and Mottl, M. J., 1983. Alkali and Sr isotope geochemistry of waters collected from basaltic basement, Hole 504B. In Cann, J. R., Langseth, M. G., Honnorez, J., Von Herzen, R. P., White, S. M., et al., Init. Repts. DSDP, 69: Washington (U.S. Govt. Printing Office), 487-494.

Honnorez, J., Laverne, C., Hubberten, H.-W., Emmermann, R., and Muehlenbachs, K., 1983. Alteration processes in Layer 2 basalts from Deep Sea Drilling Project Hole 504B, Costa Rica Rift. In Cann, J. R., Langseth, M. G., Honnorez, J, Von Herzen, R. P., White, S. M., et al., Init. Repts. DSDP, 69: Washington (U.S. Govt. Printing Office), 509-542.

Linick, T. W., 1975. Uptake of bomb-produced carbon-14 by the Pacific Ocean [Ph.D. dissert.]. University of California, San Diego. 
McDuff, R. E., 1984. The chemistry of interstitial waters from the upper ocean crust, Site 395, Deep Sea Drilling Project Leg 78B. In Hyndman, R. D., Salisbury, M. H., et al., Init. Repts. DSDP, 78B: Washington (U.S. Govt. Printing Office), 795-800.

Mottl, M. J., Anderson, R. N., Jenkins, W. J., and Lawrence, J. R., 1983. Chemistry of waters sampled from basaltic basement in Deep Sea Drilling Project Holes 501, 504B, and 505B. In Cann, J. R., Langseth, M. G., Honnorez, J., Von Herzen, R. P., White, S. M., et al., Init. Repts. DSDP, 69: Washington (U.S. Govt. Printing Office), 475-484.

Mottl, M. J., and Holland, H. D., 1978. Chemical exchange during hydrothermal alteration of basalt by seawater. I. Experimental results for major and minor components of seawater. Geochim. Cosmochim. Acta, 42:1103-1115.

Mottl, M. J., Lawrence, J. R., and Keigwin, L. D., 1983. Elemental and stable isotopic composition of pore waters and carbonate sediments from Deep Sea Drilling Project Sites 501/504 and 505. In Cann, J. R., Langseth, M. G., Honnorez, J., Von Herzen, R. P., White, S. M., et al., Init. Repts. DSDP, 69: Washington (U.S. Govt. Printing Office), 461-473.
Noack, Y., Emmermann, R., and Hubberten, H.-W., 1983. Alteration in Site 501 (Leg 68) and Site 504 (Leg 69) basalts: preliminary results. In Cann, J. R., Langseth, M. G., Honnorez, J., Von Herzen, R. P., White, S. M., et al., Init. Repts. DSDP, 69: Washington (U.S. Govt. Printing Office), 497-508.

Östlund, H. G., and Stuiver, M., 1980. GEOSECS Pacific radiocarbon. Radiocarbon, 22:25-53.

Seyfried, W. E., Jr., and Bischoff, J. L., 1979. Low temperature basalt alteration by seawater: an experimental study at $70^{\circ} \mathrm{C}$ and $150^{\circ} \mathrm{C}$ Geochim. Cosochim. Acta, 43:1937-1947.

Seyfried, W. E., Jr., and Mottl, M. J., 1982. Hydrothermal alteration of basalt by seawater under seawater-dominated conditions. Geochim. Cosmochim. Acta, 46:985-1002.

Stumm, W., and Morgan, J. J., 1970. Aquatic Chemistry: New York (Wiley).

Date of Initial Receipt: 7 November 1983

Date of Acceptance: 12 March 1984 